\title{
PROPORTIONAL AND STRUCTURAL ANALYSIS OF THE HISTORICAL TRUSS OF CHURCH OF ST. BARTHOLOMEW IN MLADOČOV
}

\author{
Peter KRUŠINSKÝ ${ }^{1,{ }^{*},}$ Jozef GOCÁL ${ }^{1}$, Michaela HOLEŠOVÁ ${ }^{1}$, Eliška RACKOVÁ ${ }^{2}$ \\ ${ }^{1}$ Faculty of Civil Engineering, University of Žilina, Univerzitná 8215/1, 01026 Žilina, Slovakia. \\ ${ }^{2}$ National Heritage Institute, Okružní 418, 55102 Jaroměř, Czech Republic. \\ corresponding author: peter.krusinsky@uniza.sk
}

\begin{abstract}
The researched truss of the Gothic Church of St. Bartholomew in the village of Mladočov is one of the examples of the use of the historical Czech length units of measurement; in this case, the Gothic and Baroque part of it. At the same time, it analyzes the proportional relationships between the individual elements of the truss. The structural analysis in relation to current standards points to the fact that the original design of the structure based on geometrical and proportional principles satisfy the reliability conditions defined by current European standards for structural design.
\end{abstract}

\section{Introduction}

The Gothic Church of St. Bartholomew in the village of Mladočov has a cross-Gothic ribbed vault in the presbytery; the nave has a wooden beamed ceiling. The trusses are dated to the years 1418 - 23d above the front part of the nave and 1723 - 4d above the presbytery and the middle part of the nave. The researched truss is a rafter-collar tie structure with collar beams and pedestal struts. It has a characteristic shape and maybe typologically be classified as a structure of the earlier period. This type of truss structure was typically built in this region and represents one of the features occurring in the particular social and cultural circles at the time, for example, St. Martin's Church in Dolní Újezd [1]. It was possible to identify the old length units that were used in the realization and that corresponds to the Czech ell used since 1268. Consequently, a numerical model of the roof structure was created in order to perform a static analysis of the roof structure in accordance with present standards. With regard to the structural analysis results, it can be said that the original design of the structure based on geometrical and proportional principles satisfy the reliability conditions defined by current European standards for structural design.

\section{History}

Village Mladočov is located $13 \mathrm{~km}$ southwest of Litomyšl near the Bohemia-Moravian border. The small village located on an elevated terrace above the valley of the river Desná includes less than a dozen homesteads with private agriculture plots. In terms of regional settlement development, it is located on the very edge of an area systematically inhabited even before the colonization boom of the 13th century.

The church of St. Bartholomew (Fig.1) was dated in the literature as early Gothic [2], apart from the possible older core, its morphology shows more to the 14th century. The construction went through several development phases. The Gothic core consists of a square presbytery with corner supports and a cross rib vault and an adjacent part of the additionally extended nave. A spacious sacristy was soon added to the north side of the presbytery. In the attic of the church, a brick gable has been preserved above the triumphal arch.

On its side above the presbytery, the imprint of the original roof with a slope of $51^{\circ}$ is clearly visible, to which a less sloping sacristy roof was connected on the northern side. The church was probably damaged by Hussite troops in the spring of 1421 [3], and a new truss was erected above the 
nave and presbytery. While the entire structure has been preserved above the nave of the church to this day, only another imprint of the steep asymmetrical roof remains above the presbytery after the roof, on the south side with a slope of $60^{\circ}$, on the north side above the extension of the sacristy $51^{\circ}$. At the beginning of the 16th century, a longitudinal vestibule was added to the northern entrance, on the western side with a later abolished entrance to the gallery.

After 1723, the church was thoroughly rebuilt and expanded. The Gothic western wall was planned, on the south side of the presbytery with extending beyond the building itself. Although the form of the church was completely changed, the structure of the late Gothic truss was preserved and the nave was extended to the west, where was build a decreased vestibule. The church was newly roofed, on the west ending with a triangular gable wall. Earlier gable wall was only demolished below the roof [4]. The church underwent the last significant reconstruction at the beginning of the 20th century. Part of the newly attached truss was finished with a new brick gable.

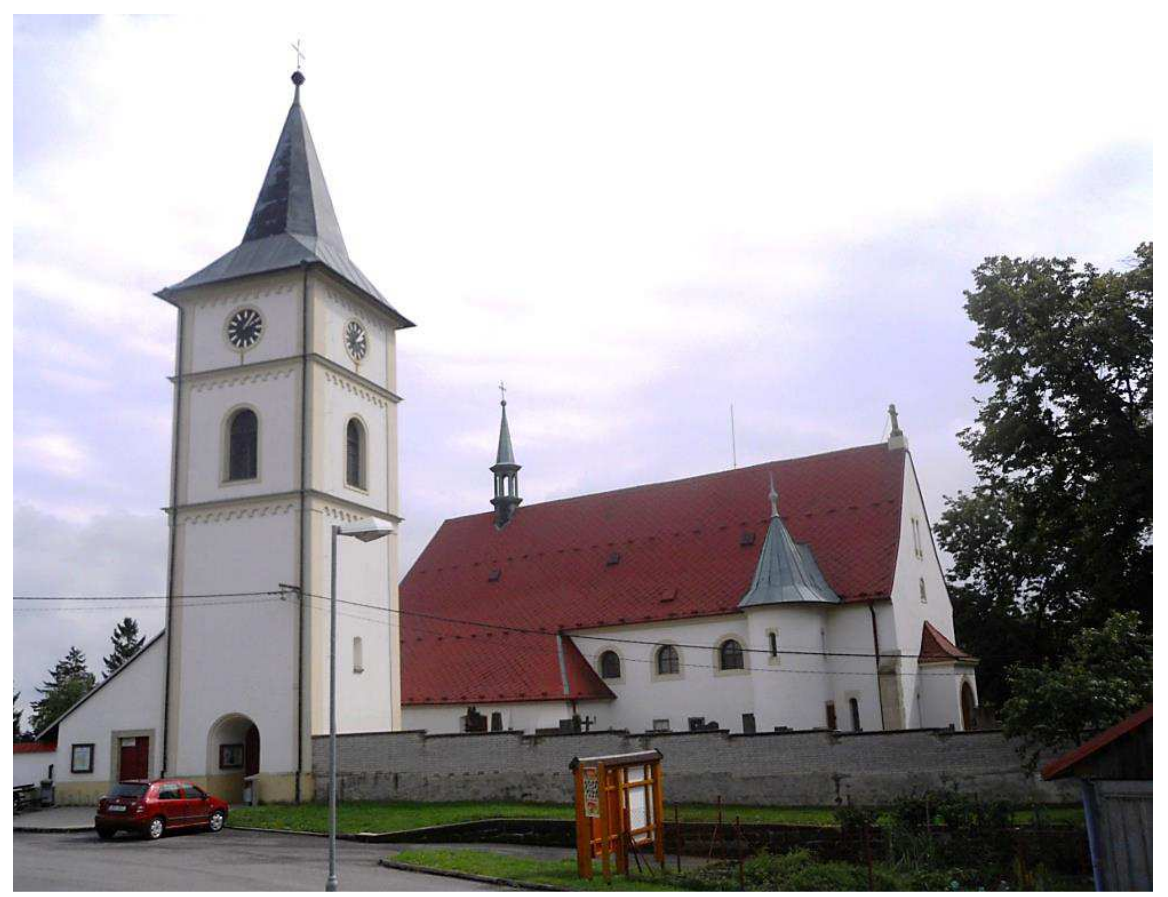

Fig. 1: The church of St. Bartholomew in the village of Mladočov [5].

\section{Truss construction}

The late Gothic part of the truss consists of five principal and four secondary transversal trusses. The rafters form an angle of $59.3^{\circ}$ with the tie beams. The rafter truss has developed transversal and longitudinal bracing. The principal rafters $(A)$ have heel struts and a high-positioned collar beam. Two pairs of slope struts running from the middle post to the tie beams and rafters create a characteristic slightly sloping diamond pattern at the bottom. The principal rafters $(B)$ are reinforced by high-positioned collar beams, heel struts and St. Andrew's crosses too. Longitudinal stiffening of the truss is ensured by a crossbeam located $1.6 \mathrm{~m}$ below the girders. This is intersected by steep St. Andrew's crosses connecting full ties. The truss elements are relatively cleanly hewn out from fir wood and often overlapped. All original lap joints are dovetailed, uncovered, secured with wooden nails. Assembly marks form simple bevels with an ax. Transverse trusses are numbered from east I - IIIIIIII, longitudinal St. Andrew's crosses from west I (number omitted or not preserved) - III (IIII removed). In the first two trusses from the east, all elements except the rafters were removed due to the installation of the turret structure, and in the other trusses, the tie beams were replaced, Fig. 2.

The truss above the presbytery is dated to the years $1723-4 d$, above the front part of the nave 1418-23d, in the last stage of the extension of the nave 1723 - $4 d$ and above the gallery at the beginning of the 20th century, Fig. 3. 


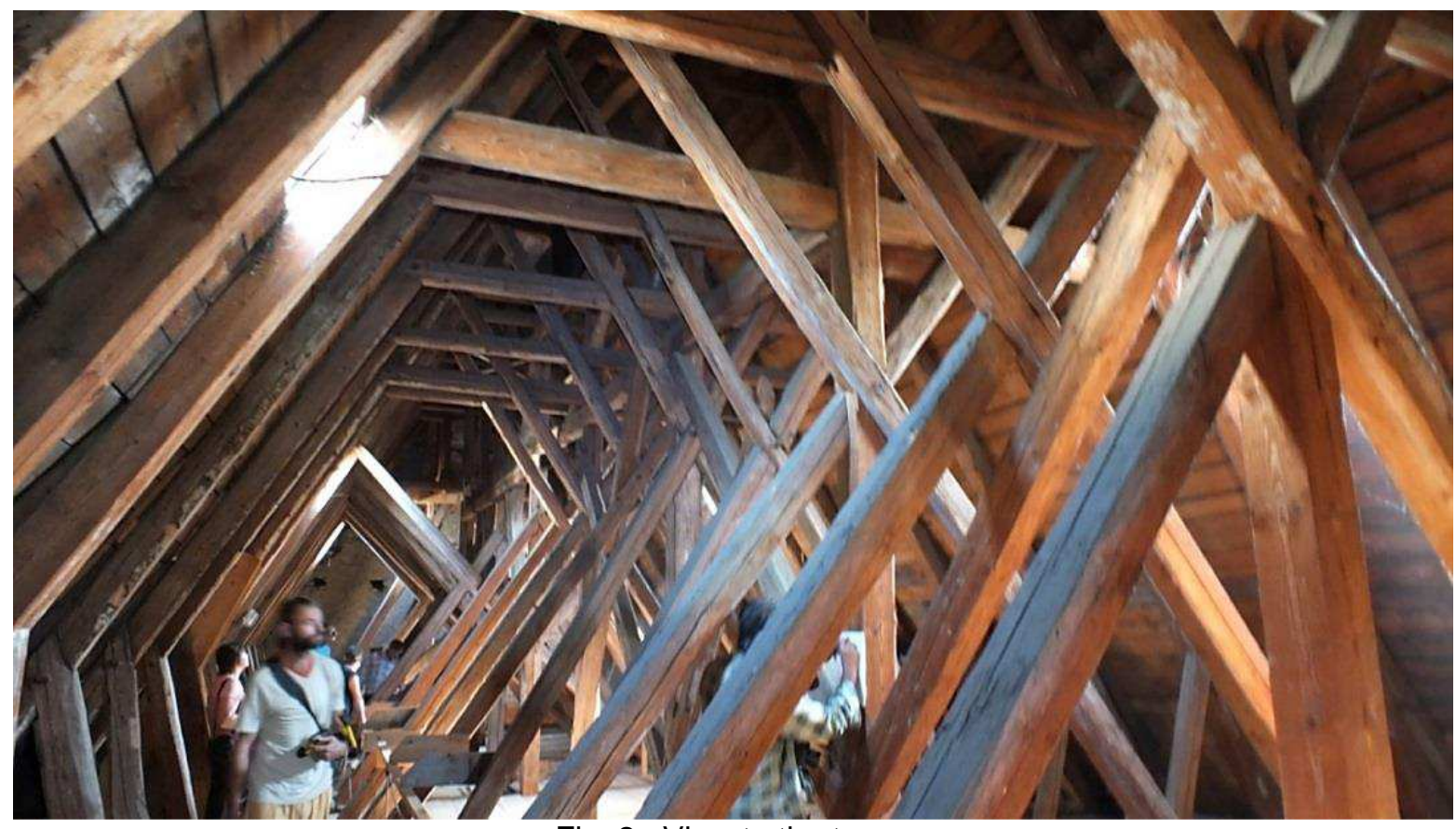

Fig. 2: View to the truss.

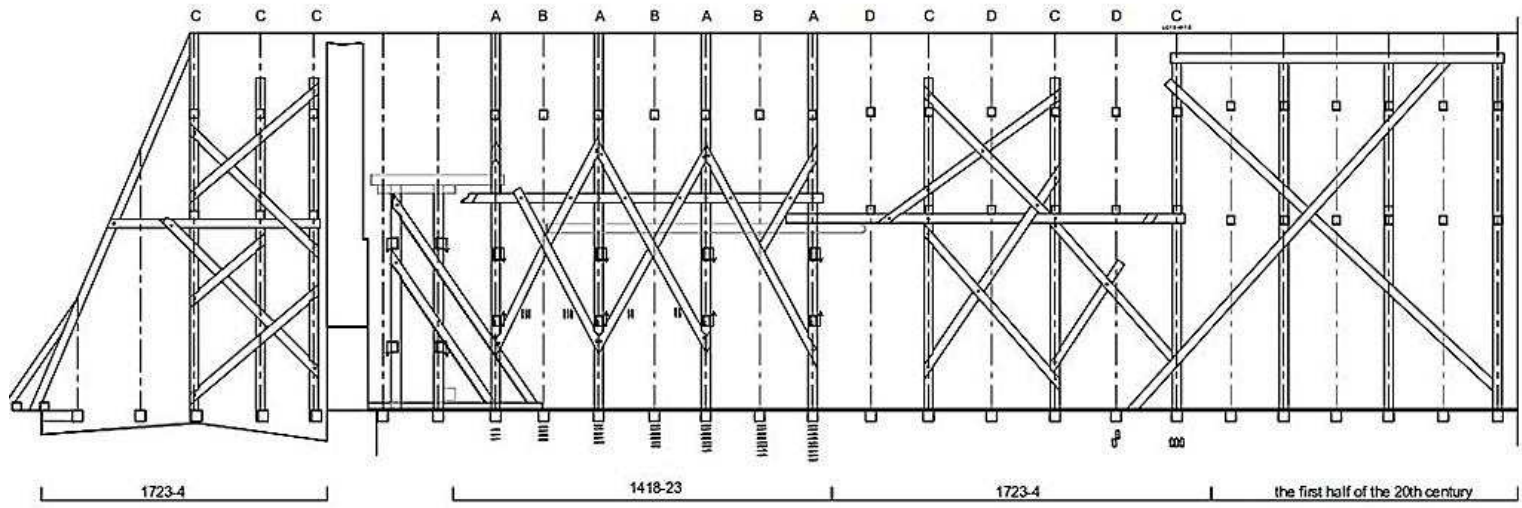

Fig. 3: The longitudinal section shows framing in a vertical plane under the ridge of the roof above both presbytery and nave.

\section{Geometry and proportion concept of truss design}

Based on the analysis of conditions and length units, the most probable local length unit was the Czech ell (Prague or Old Town), which was also used in Litomyšl with a length of $593 \mathrm{~mm}$ and a foot of $296.5 \mathrm{~mm}$. The use of the uniform units was ordered by Premysl Otakar II from 1268. It was used in Litomyšl from 1370 - 1763. [6] All vertical bonds are realized in one length unit.

According to the data obtained, we do not know the exact location of the wall beam, but based on other structural elements, we assume that the total width of the church may be 33 feet, which is a known number as the years of Christ. The ratio of half the width of the truss to the height of the truss fathoms (one fathom is 5 feet) is $3 / 5$. In this case, the principle is "n plus $k$ " to determine the height of the truss from its width for the fathom, where $n=3$ and $k=2$, so the width of the truss is 6 fathoms and the height of the truss is 5 fathoms, Fig. 4. 
A

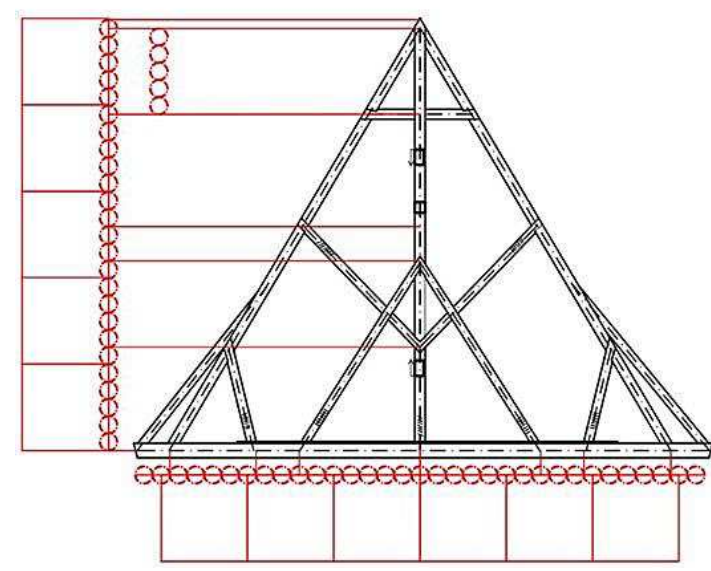

B

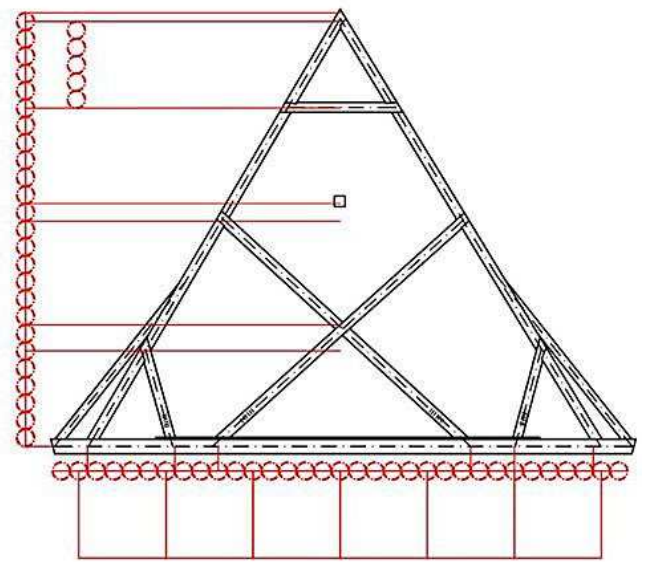

Truss $A$ and Secondary Truss B.

There are four types of trusses A, B, C, D in the church. We can assume that the truss structure also depended on the basic square, the side of which has a length equal to half the width of the truss. The height of the truss could also be determined by means of a circle having a center at the vertex of this base square and a radius equal to half the length of the diagonal of the base square, Fig. 5 . What is more interesting, however, is that in the truss A, the location of the spurs is such that it is parallel to the diagonal of the base square and also with the beam include 45 degrees' angle.

Furthermore, for bond A of the truss, it is valid that the placement of the spurs on the rafters is 7 feet above the location of the connection of these struts on the central post and the placement of the spurs on the rafter divides the truss height by ratio $12 / 13$. The connection of the spurs is placed on the central post 6 feet above the tie beam.

The location of the collar beam is 5 feet ( 1 fathom) from the top of the truss, while the distance is determined axially and it is $1 / 3$ of half the width of the truss. The heel struts of the rafter are located 5 feet ( 1 fathom) from the rafter on the tie beam.

The height of the location of the joint of the heel struts of the column to the height of the truss is in the fathoms in the ratio $11 / 25$, i.e. the height of the truss is divided by this connection in the ratio 11/14. The heel struts of the central post are located on the tie beam at the distance of 7 feet from the post.

The truss $C$ contains two collar beams. The lower collar beam is positioned so that the height of the truss in the ratio $11 / 14$ is divided by it. The upper collar beam is 6 feet away from the lower collar beam and is at $4 / 5$ of the truss height. The struts of rafters are located 4 feet from the rafter on the beam. Furthermore, for the bond $C$ of the truss, it is valid that the spurs on the rafters divides the distance between the upper and lower collar beams in a ratio of $1 / 2$, Fig. 6 .

The height of the location of the joint of the heel struts of the column to the height of the truss is in the fathoms in the ratio $11 / 25$, i.e. the height of the truss is divided by this connection in the ratio $11 / 14$. The heel struts of the column are located on the tie beam at the distance of 7 feet from the central post.

A

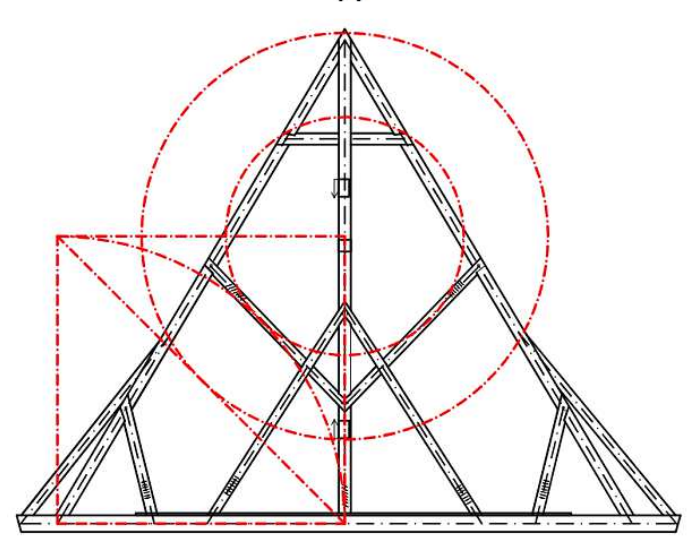

Fig. 5 Base square and define the spurs. 
The principal truss $C$ contains two collar beams. The lower collar beam is positioned so that the height of the truss in the ratio $11 / 14$ is divided by it. The upper collar beam is 6 feet away from the lower collar beam and is at $4 / 5$ of the truss height. The struts of rafters are located 4 feet from the rafter on the beam. Furthermore, for the bond $C$ of the truss, it is valid that the spurs on the rafters divides the distance between the upper and lower collar beams in a ratio of $1 / 2$, Fig. 6 .

The height of the location of the joint of the spurs to the height of the truss is in the fathoms in the ratio $11 / 25$, i.e. the height of the truss in the ratio $11 / 14$ is divided by this connection. The heel struts of the central post are located on the beam at the distance of 6 feet from the central post. The struts are attached to the lower collar beam one foot from the center post. The central post ends in half the distance between the upper collar beam and the top of the truss.

C

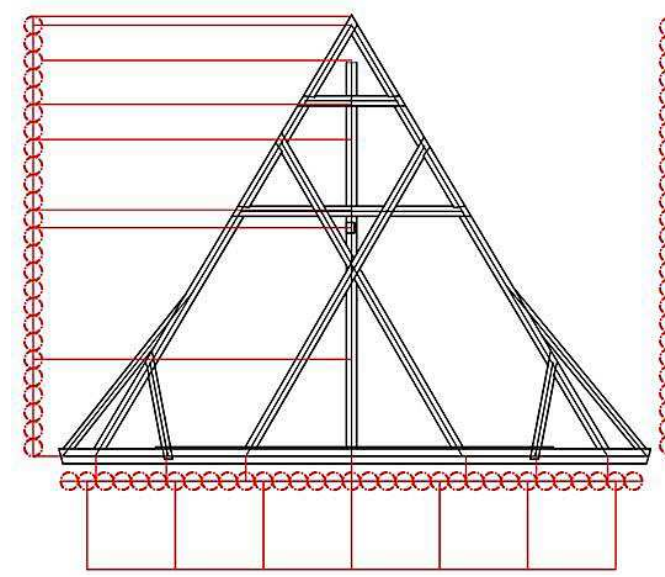

Fig. 6: Proportional analysis of Principal Truss C and Secondary Truss D.

\section{Structural analysis of the cross trusses}

Numerical model of the roof structure was developed in the software SCIA Engineer [7] using finite element method (FEM). Each of the cross trusses described in the geometrical analysis presented hereinbefore were modelled separately by means of planar models using beam elements. All the member connections are modelled as hinged with capability of initial slip of $1 \mathrm{~mm}$ in the axial direction of the connected member in order to consider an influence of possible gaps in historical carpentry joints. The effect of local weakening of the cross sections using carpentry joints is neglected in the models. The isotropic material model with mechanical properties of C24 according to [8] was considered, which corresponds to the applied type of wood. Geometrical schemes of the numerical models of the individual cross trusses are presented in Fig. 7.
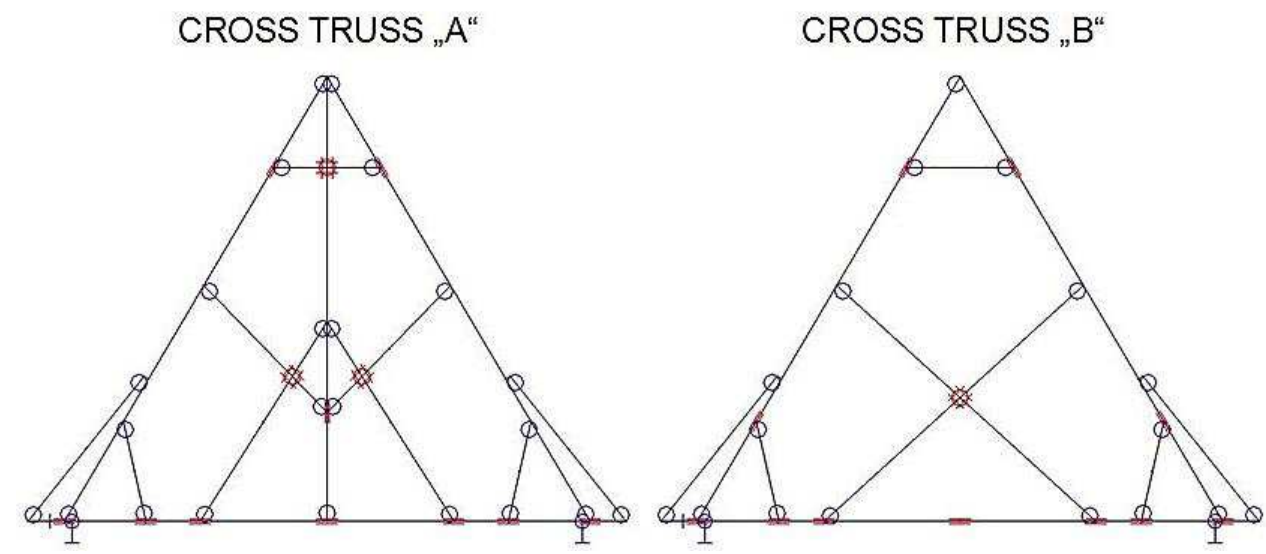

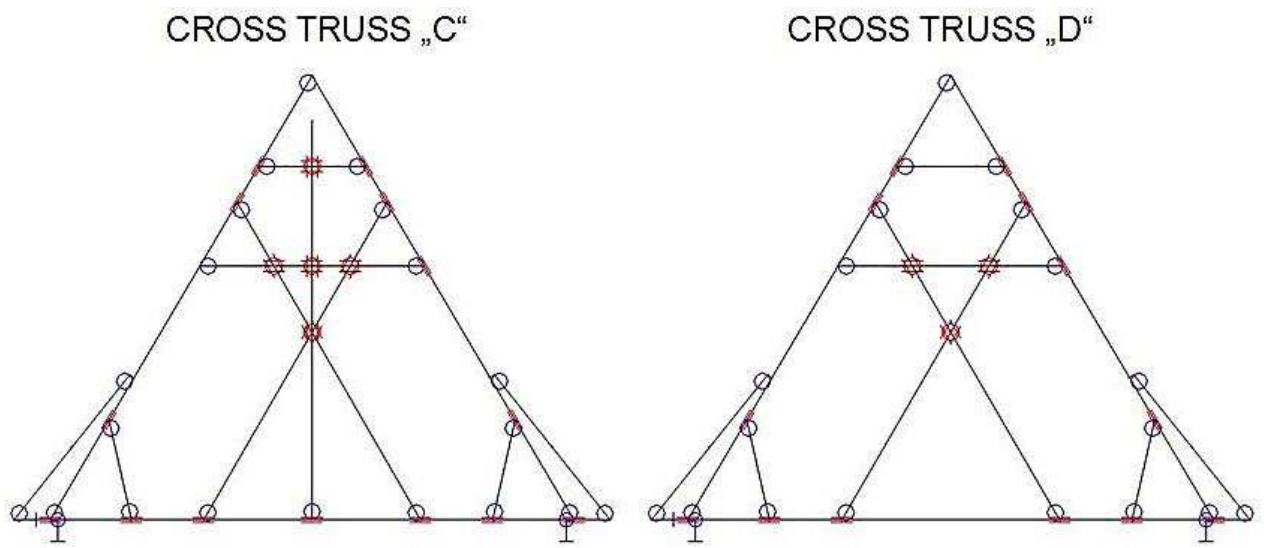

Fig. 7: Geometrical schemes of the numerical models.

To verify the static behaviour of the individual cross trusses, the loads according to European standards [9-11] were applied in the models, namely the permanent loads (self-weight and weight of roofing) and wind actions. With regard to the roof pitch angle (about $60^{\circ}$ ), the snow load was not applied on the roof. The self-weight load was generated by the FEM software. The combinations of load cases were generated according to the standard STN EN 1990 [9].

The results of numerical analysis are presented by the values of maximum normal stresses and displacements in the major structural members of the cross trusses, calculated for the decisive load combinations. The envelopes of maximum (tension) and minimum (compression) normal stresses in the major cross truss members are presented in Fig. 8. The presented values do not include possible buckling effects, which are negligible because of low share of compression forces (caused mainly by permanent loads). The envelopes of local vertical deformations of the main cross truss members caused by characteristic load combinations are presented in Fig. 9.
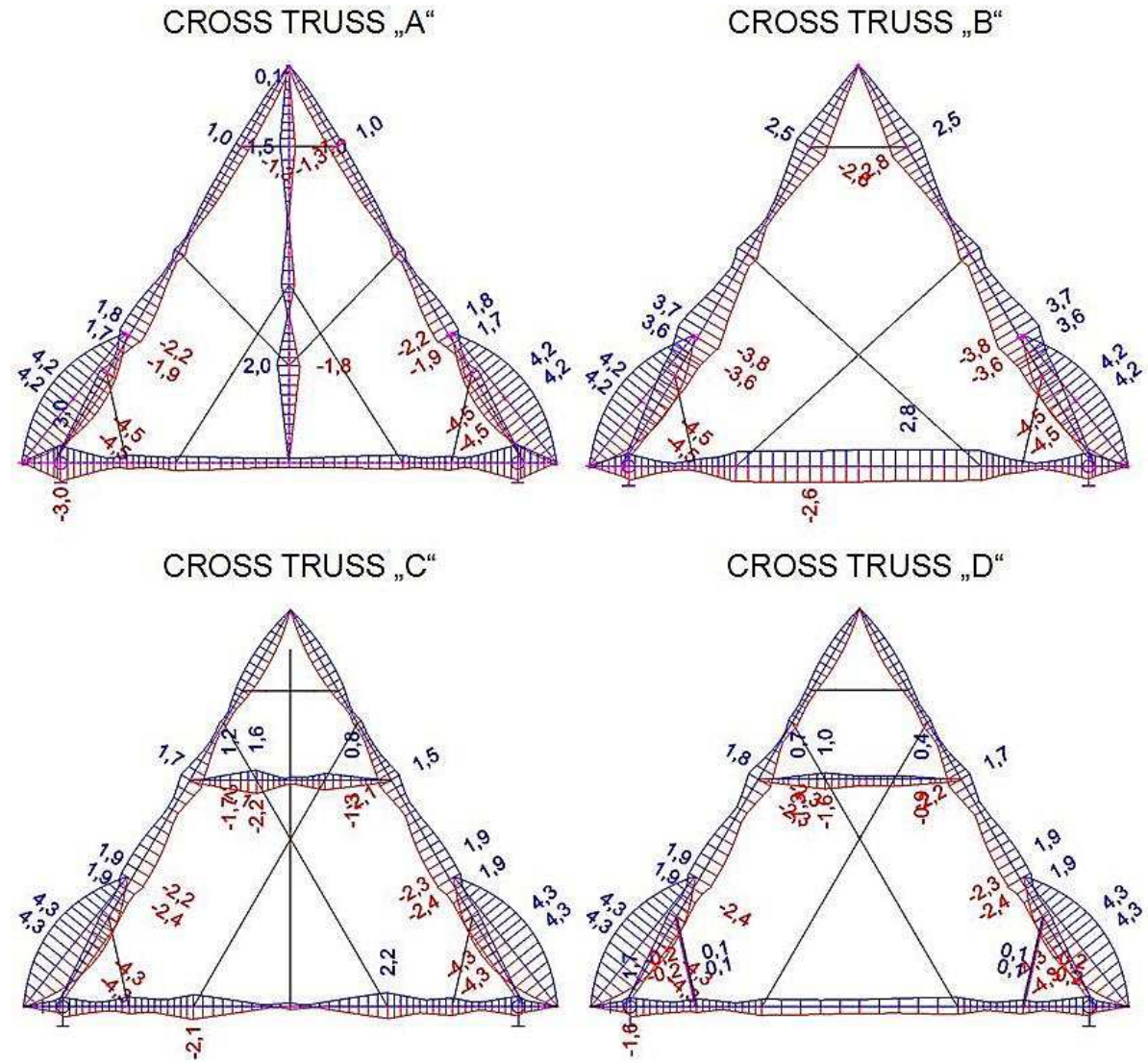

Fig. 8: Normal stresses (MPa) in the major cross truss members. 

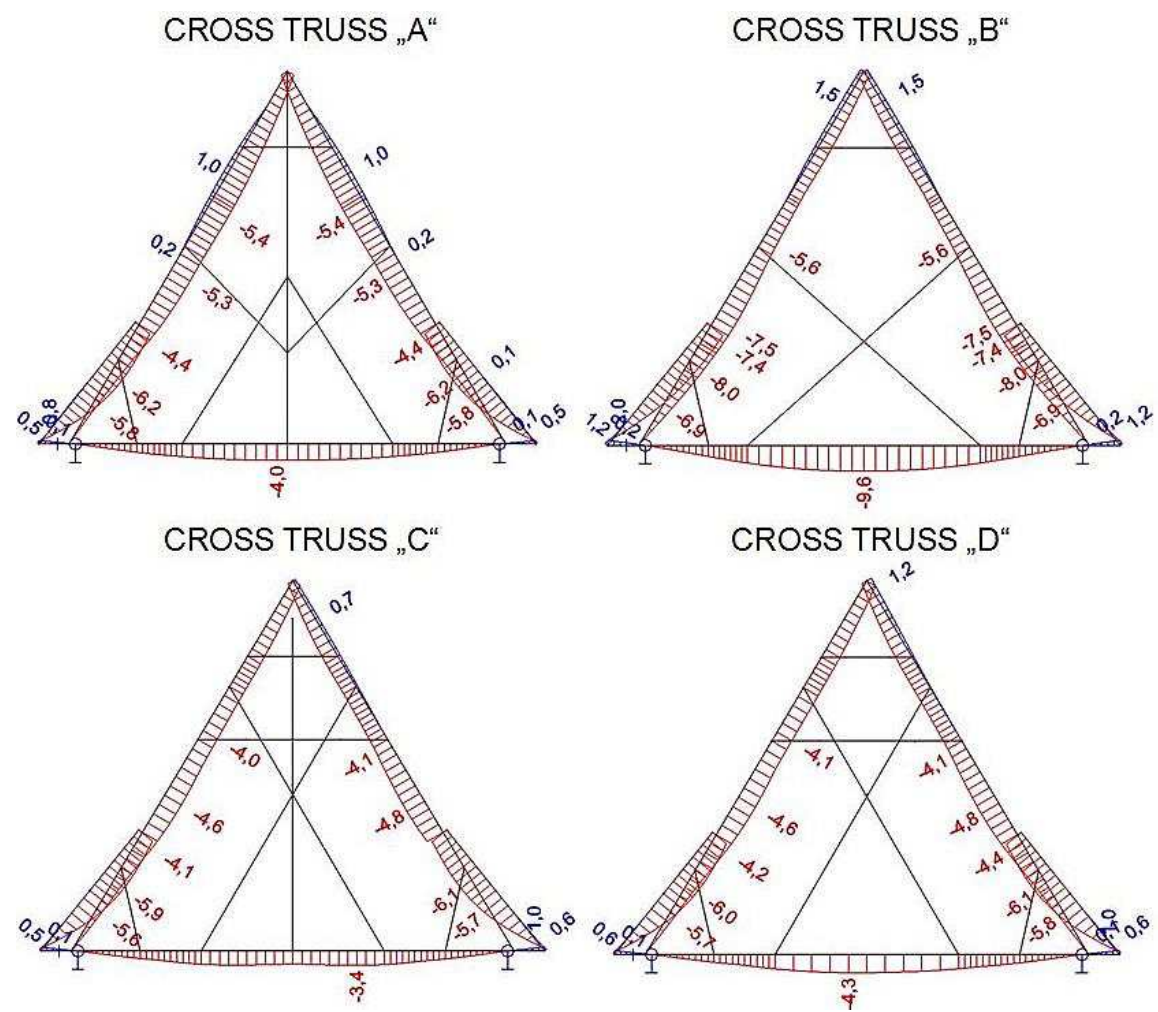

Fig. 9: Vertical deformations $(\mathrm{mm})$ in the major cross truss members.

\section{Conclusion}

The local length of the Czech Ell $(593 \mathrm{~mm})$ was identified by the analysis in the truss and was used in its realization at the Gothic (binding $A$ and $B$ ) and baroque (binding $C$ and $D$ ) stages. The use of the basic square to determine the height and connection of the rafter and the truss element was also found in the truss (date 1409d) of the church in the village of Bela-Dulice in Slovakia [13], Fig. 10. As in other investigations of trusses, in this case, the principle of the principle "n plus $\mathrm{k}$ " was to determine the height of the church depending on its width. For example at the trusses of churches in Dolný Újezd [1], St. Catherine in Banská Štiavnica [14], Klimkovice [15], St. Nicolaus in Podunajské Biskupice [16], St. Cozma and Damianus in Abramova [17] and others [18].

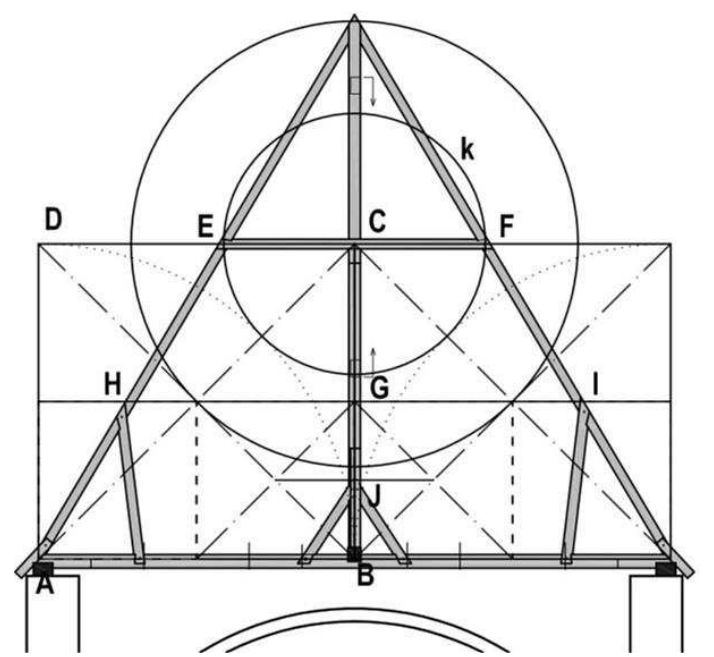

Fig. 10: Geometrical analysis of principal transversal truss in Roman Catholic church in Bela-Dulice [13].

The results of numerical analysis show that the normal stresses in all truss members do not exceed the design values of bending strength and compression strength equal to $16.60 \mathrm{MPa}$ and $14.53 \mathrm{MPa}$, respectively, assuming the timber strength class C24, modification factor $k_{\bmod }=0.9$ and 
partial safety factor $Y_{M}=1.3$ (according to STN EN 1995-1-1 [12]). A considerable reserve in the normal stresses safely covers the small buckling effects as well as the effect of weakening of cross sections at the carpentry joints. Similarly, the maximum vertical deformations of the major cross truss members do not exceed the standard [12] limit values (for example, the limit value of vertical deformation of the tie beam is equal to $L / 200=8363 / 200=41.8 \mathrm{~mm}$ ).

\section{Acknowledgements}

This paper presents results of works supported by the VEGA - Grant Agency of the Slovak Republic under the project VEGA 1/0537/18.

\section{References}

[1] KRUŠINSKÝ, P. - GOCÁL, J. - HOLEŠOVÁ, M.: Geometric and static analysis of the historical truss of the medieval truss Church of St. Martin in Dolní Újezd. XXIX R-P-S Seminar 2020 November 2020, Wroclaw, Poland IOP Conf. Ser.: Mater. Sci. Eng. 1015 012042, doi https://doi.org/10.1088/1757-899X/1015/1/012042.

[2] WIRTH, Z. - MATĚJKA, B. - ŠTĚPÁNEK, J.: Soupis památek historických a uměleckých v království Českém od pravěku do počátku XIX. století. XXIX. Politický okres Litomyšlský, Praha, 1908.

[3] POCHE, E.: Umělecké památky Čech 2 (Artistic monuments of Bohemia) - cz 2. Academia, Praha, 1978.

[4] KYNCL, T.: Research Report No. 135a - 16. Dendrochronological dating of wooden structural elements of the trusses of the church in Mladočov - cz, Brno, 2016. Unpublished typescript stored in the archives of the NPÚ ÚOP in Pardubice.

[5] https://cs.wikipedia.org/wiki/Mlado\%C4\%8Dov\#/media/Soubor: Mladocov_sv_Bart_od_SZ_DSCN 4779.JPG

[6] SEDLÁČEK, A.: Paměti a doklady o staročeských mírách a váhách. (Memories and Evidence of Old Bohemian Measures and Weights). Czech Academy of Sciences and Arts, Prague, 1923.

[7] SciaEngineer 2020. Software for structural analysis. https://www.scia.net/sk.

[8] STN EN 338 Structural timber. Strength classes. SÚTN, Bratislava, 2010.

[9] STN EN 1990 Eurocode. Basis of structural design. SÚTN, Bratislava, 2009.

[10] STN EN 1991-1-1 Eurocode 1. Actions on structures. Part 1-1: General actions. Densities, selfweight, imposed loads for buildings. SÚTN, Bratislava, 2007.

[11] STN EN 1991-1-4 Eurocode 1. Actions on structures. Part 1-4: General actions - Wind actions. SÚTN, Bratislava, 2007.

[12] STN EN 1995-1-1 + A1 Eurocode 5. Design of timber structures. Part 1-1: General. Common rules and rules for buildings. SÚTN, Bratislava, 2008.

[13] KRUŠINSKÝ, P. - CAPKOVÁ, E.: Geometric analysis of the truss above the nave and presbytery of the roman-catholic church in village Bela Dulice. Contemporary problems of architecture and construction, 6th international conference, 4th - 27th June 2014, Ostrava, Czech Republic, VŠB Technical University, Faculty of Civil Engineering.

[14] KRUŠINSKÝ, P. - GOCÁL, J. - HOLEŠOVÁ, M.: Geometric and static analysis of the historical truss of the Saint Catherine church in Banska Stiavnica. Proceedings of the international conference on Structural health assessment of timber structures, Guimarães, Universidade do Minho, 2019, pp. 288-296.

[15] AUGUSTINKOVÁ, L. - KRUŠINSKÝ, P. - KORENKOVÁ, R. - HOLEŠOVÁ, M.: Analysis of geometric conception of the historical truss Church of Holy Trinity in Klimkovice. SGEM 2017, International multidisciplinary scientific conference on social sciences \& arts: urban planning, architecture \& design conference proceedings Book 5, 28 - 31 March 2017, Vienna, Austria. Vol. I, Architecture and design, pp. 37-43.

[16] BOTEK, A. - ERDÉLYI, R. - PAULINY, P. - VACHOVÁ, B.: Roman Catholic Church of St. Nicolaus in Podunajské Biskupice. Architectural and historical research and restoration design /The Regional Monuments Board Bratislava, Bratislava, 2016, $304 \mathrm{p}$.

[17] KRUŠINSKÝ, P. - GOCÁL, J. - HOLEŠOVÁ, M.: Geometric and static analysis of the historical trusses in roman catholic church of the holy Kozma and Damian in the Abramová village. Civil and Environmental Engineering, Vol. 11, Iss. 2, 2015, pp. 136-141.

[18] GRÚŇOVÁ, Z. - HOLEŠOVÁ, M.: Columnar entasis in Vignola's and other renaissance works. Civil and Environmental Engineering, Vol. 14, Iss. 2, 2018, pp. 132-137. 